\title{
Pendampingan Peningkatan Kapasitas Skill Microsoft Word Guru Di SD Negeri 173529 Tampahan Kabupaten Toba Samosir
}

\author{
Sinta Dameria Simanjuntak, Ari Usman \\ Universitas Katolik Santo Thomas Medan, Universitas Harapan Medan \\ Email:sh1_nta@yahoo.com, ariusman09@gmail.com
}

\begin{abstract}
:
The problem of partners in Community Service Activities is that teachers are not able to operate computers or laptops properly. As a result of these conditions, the teacher is unable to use Microsoft Word smoothly. On the other hand, the use of Microsoft Word is very necessary for teachers both for administrative purposes, the need for the preparation of scientific work or the preparation of teaching materials. The solution used to overcome partner problems is through Microsoft Word learning activities. The learning method implemented is through group discussions, deliberations, internal training and workshops. The results obtained were an increase in partner knowledge in operating Microsoft Word and the teacher gave a positive response to the training activities.
\end{abstract}

Keyword: Microsoft Word, Training, Response

\section{Pendahuluan}

Zaman sekarang adalah jaman digital. Zaman digital ditandai dengan melek teknologi. Hal senada juga disampaikan Ismail ${ }^{1}$ yang menyatakan bahwa era digital ditentukan oleh kekuatan pemikiran dan kekuatan teknologi.

Melek teknologi artinya mampu mengintegrasikan teknologi dalam pembelajaran. Kemampuan guru mengintegrasikan teknologi dalam pembelajaran sesuai dengan tuntutan 12 kompetensi dasar yang harus dimiliki guru. Kompetensi guru tersebut diuangkapkan Depdikbud dalam Pianda ${ }^{2}$ yaitu menyusun rencana pembelajaran, melaksanakan pembelajaran, menilai prestasi belajar, malaksanakan

\footnotetext{
${ }^{1}$ M A A Ilyas Ismail, The True Da'wa: Menggagas Paradigma Baru Dakwah Era Milenial: Edisi Pertama (Prenada Media, 2018). 187.

${ }^{2}$ Didi Pianda, Kinerja Guru: Kompetensi Guru, Motivasi Kerja Dan Kepemimpinan Kepala Sekolah (CV Jejak (Jejak Publisher), 2018). 17.
} 
tindak lanjut hasil penilaian, memahami landasan pendidikan, memahami tingkat perkembangan siswa, memahami pendekatan pembelajaran yang sesuai dengan materi pembelajaran, menerapkan kerja sama dalam pembelajaran, memanfaatkan kemajuan IPTEK dalam pendidikan, menguasai keilmuan dan keterampilan sesuai materi pembelajaran dan mengembangkan profesi. Dengan demikian seorang guru harus mampu melibatkan teknologi terbaru dalam pembelajaran kelas.

Kesenjangan kompetensi guru di desa dan guru di kota harus diakui memiliki jarak yang lebar. Guru di kota mayoritas sudah mampu melibatkan teknologi dalam pembelajaran. Sebaliknya guru di desa cenderung hanya melakukan pembelajaran secara tradisional dengan metode ceramah. Kesenjangan tersebut bukan karena perlakuan pemerintah yang berbeda kepada guru-guru di desa dan kota, melainkan karena kemauan guru di desa untuk mengembangkan profesionalnya masih rendah.

Di desa persaingan kompetensi guru rendah. Rutinitas guru di desa cukup sampai pada mengajar dan melakukan tugas sehari-hari yaitu melaksanakan kegiatan belajar. Di desa sekolah pesaing jarang. Di dalam satu daerah hanya terdapat satu sekolah. Sehingga sekolah tidak memiliki rasa takut jika peminat sekolah tersebut tidak ada. Hal tersebut juga menjadi salah satu penyebab guru di desa tidak merasa terancam untuk tenggelam dalam persaingan dan harus dituntut mengembangkan kompetensi profesionalnya.

Lima tahun terakhir ini, desa Tampahan mengalami perkembangan semenjak dikembangkan menjadi kecamatan Tampahan. Kemajuan pendidikan semakin diperhatikan oleh pemerintah setempat. Beberapa sekolah sudah mulai berbenah untuk lebih baik. Akibatnya SD negeri 173529 mengalami pengurangan jumlah murid karena menurut masyarakat kualitas pembelajaran menurun. Pemikiran orang tua siswa juga sudah semakin maju dengan rela menyekolahkan anaknya ke sekolah yang lebih jauh dan biaya yang lebih mahal demi peningkatan mutu pendidikan anak-anaknya. 
Fakta tersebut harus menyadarkan guru-guru di SD Negeri 173529 untuk berbenah. Dimulai dari hal sederhana yaitu dengan pengetahuan dasar dalam penggunaan teknologi seperti penggunaan laptop untuk menunjang profesi guru. Aplikasi paling dasar yang harus dikuasi adalah aplikasi Ms. Word sebagai titik tolak untuk mengembangkan pengetahuan teknologi lainnya.

\section{Metode}

Kegiatan PKM ini dilaksanakan di SD Negeri 173529 Tampahan yang terletak di desa Tampahan Kecamatan Tampahan Kabupaten Toba Samosir. Kegiatan dilaksanakan pada tanggal 11 Mei 2019.

Metode pendekatan yang digunakan adalah metode pendekatan yang diadaptasi dari pendapat Mudlofir ${ }^{3}$ tentang strategi pengembangan profesionalitas guru. Beberapa pendekatan yang akan dilakukan adalah diskusi kelompok, musyawarah, pelatihan internal dan workshop.

Diskusi kelompok berguna untuk bertukar pikiran antar sesama guru dan kelompok tim pengusul PKM untuk membahas solusi masalah yang dihadapi secara bersama.Musyawarah berguna untuk bersama-sama mengembangkan suatu program kerja dalam mengatasi masalah yang dihadapi. Pelatihan internal atau InHouse Training (IHT) adalah pelatihan yang dilaksanakan secara internal pada kelompok kerja guru atau sekolah pada suatu tempat yang telah disepakati. Workshop adalah kegiatan yang diharapkan menghasilkan produk pembelajaran dari kelompok guru mitra setelah mendapatkan pelatihan-pelatihan.

Evaluasi dilaksanakan untuk menilai ketercapaian kegiatan. Model evaluasi yang digunakan adalah model evalusi kuisioner. Menurut Sudijono ${ }^{4}$ kuisioner digunakan untuk menilai hasil belajar dalam bentuk pernyataan. Kuisioner yang diberikan adalah kuisioner dalam bentuk angket tertutup dengan

\footnotetext{
${ }^{3}$ Ali Mudhofir, Pendidik Profesional: Konsep, Strategi, Dan Aplikasinya Dalam Peningkatan Mutu Pendidikan Di Indonesia (Jakarta: Raja Grafindo Persada, 2012). 131.

${ }^{4}$ Anas Sudijono, Pengantar Evaluasi Pendidikan (Jakarta: PT RajaGrafindo, 1998). 84.
} 
pilihan Ya atau Tidak yang dimodifikasi dari penelitian Bornok Sinaga pada tahun 2008..$^{5}$ Angket yang digunakan tersebut terdiri atas 4 aspek yaitu aspek suka atau tidak suka, baru atau tidak baru, berminat atau tidak berminat dan tertarik atau tidak tertarik. Tujuan keempat komponen angket tersebut adalah untuk mengetahui respon guru terhadap kegiatan yang dilaksanakan.

Hasil pretest, posttest dan angket dianalisis dengan menghitung skor total dari setiap tes dan angket yang digunakan. Setelah skor total diperoleh, rata-rata dari setiap tes dihitung dengan menggunakan rumus rata-rata. Skor untuk respon juga dihitung dengan cara yang sama namun dalam bentuk persen.

\section{Hasil dan Pembahasan}

\section{Kondisi Eksisting SD Negeri 173529 Tampahan Toba Samosir}

SD Negeri 173529 Tampahan adalah Sekolah Dasar yang berada di Desa Tampahan Kecamatan Tampahan Kabupaten Toba Samosir. Sekolah ini berada di lingkungan gereja HKBP Tampahan. Gedung yang dimiliki sekolah terdiri dari dua gedung yaitu gedung milik gereja dan gedung milik pemerintah. Gedung milik pemerintah terdiri dari 4 bilik yang belum dialiri listrik. Gedung milik gereja terdiri dari 3 bilik dan sudah dialiri arus listrik. Sekolah ini masih menggunakan kapur dan papan tulis blackboard dalam proses belajar mengajar. Ruang kepala sekolah, kantor guru dan gudang penyimpanan inventaris sekolah berada dalam satu bilik. Dengan demikian tidak ada ruang khusus untuk guru, untuk kepala sekolah dan untuk penyimpanan barang atau inventaris sekolah. Sekolah ini tidak memiliki ruang UKS jika seandainya ada siswa yang kurang sehat. Kamar mandi terdiri dari dua bagian yaitu untuk laki-laki dan untuk perempuan. Namun kondisi kamar mandi sangat tidak baik untuk kesehatan karena kotor dan berbau. Hal tersebut terjadi karena tidak ada saluran air ke kamar mandi. Jika diperlukan, air diambil dalam wadah dari saluran air sawah yang dekat dengan sekolah.

\footnotetext{
${ }^{5}$ Bornok Sinaga and Manguji Nababan, Pengembangan Model Pembelajaran Matematika Berdasarkan Masalah Berbasis Budaya Batak (PBM-B3) (Medan: FMIPA Unimed, 2008).
} 
Guru yang mengajar di SD Negeri 173529 terdiri dari 10 orang. 9 orang adalah perempuan dan 1 orang laki-laki yang merupakan kepala sekolah di sekolah tersebut. Dari 10 guru tersebut, 1 guru sudah mendekati masa pensiun sehingga sudah tidak produktif lagi ke sekolah. Guru-guru tersebut masing-masing adalah guru kelas untuk kelas 1 - kelas 6. Dua orang guru yang lain masing-masing merupakan guru Pendidikan Agama Kristen (PAK) dan guru olahraga. Guru dengan latar belakang SPd, SD masih satu orang yaitu Bapak Kepala Sekolah. Selebihnya adalah guru dengan latar belakang pendidikan S.Pd.

Peminat dari sekolah ini selama 5 tahun terakhir mengalami penurunan. Jumlah siswanya dari tahun ke tahun semakin berkurang. Menurut info yang diperoleh dari masyarakat, kualitas pembelajaran berkurang. Akibatnya, orang tua memilih sekolah yang berada di luar desa Tampahan yang menurut mereka memiliki kualitas belajar yang lebih baik. Beberapa orang tua rela mengantar anaknya sekolah dengan jarak yang lebih jauh dan dengan biaya yang lebih mahal.

Berdasarkan hasil wawancara diperoleh informasi bahwa guru-guru tidak melek dengan penggunaan teknologi. Salah satunya adalah penggunaan komputer atau laptop. Karena kondisi tersebut, Data Pokok Pendidikan (Dapodik) diupahkan pada orang lain. Sehingga sekolah ini tidak memiliki operator sekolah. Dalam hal kenaikan pangkat, guru menyewa jasa orang lain untuk menyusun karya ilmiah. Untuk keperluan administrasi ke Dinas Pendidikan seperti RPP, guru mengunduhnya dari internet kemudian mengganti-ganti hal yang dirasakan tidak perlu. Untuk kegiatan belajar mengajar, guru hanya memakai buku yang tersedia tanpa dikembangkan dalam bentuk bahan ajar.

Dinas Pendidikan sering melakukan kegiatan seminar, pelatihan dan workshop untuk meningkatkan kompetensi guru. Namun berdasarkan pengakuan guru, mereka tidak pernah memanfaatkan laptop yang mereka bawa pada saat seminar/pelatihan/workshop karena tidak paham dalam menggunakannya. Akibatnya, kegiatan yang dilakukan oleh pemerintah tersebut tidak memberikan 
kontribusi yang signifikan bagi peningkatan kompetensi guru. Kualitas proses belajar mengajar tidak mengalami peningkatan.

Berdasarkan fakta-fakta yang ditemui di lapangan tersebut, diperlukan pendekatan yang lebih bersifat internal. Pendekatan tersebut dilaksanakan dalam bentuk pelatihan dan loka karya (workhsop). Metode tersebut dipilih berdasarkan pertimbangan atas keberhasilan kegiatan penelitian atau pengabdian sebelumnya yang telah berhasil dalam memperbaiki masalah yang relevan dengan masalah pendampingan masyarakat ini.

Kegiatan tersebut diantaranya adalah kegiatan yang dilaksanakan oleh Nugroho, dkk memberikan hasil bahwa kegiatan pelatihan membantu siswa dan guru untuk mempelajari aplikasi program sederhana dan terus mengembangkannya secara mandiri ${ }^{6}$. Selanjutnya kegiatan yang dilakukan oleh Budiana, dkk memberikan hasil bahwa pelatihan membuat guru memiliki pengetahuan dan pemahaman keberagaman aplikasi ICT seperti Ms. Word ${ }^{7}$.

Sesuai dengan kajian diatas, diharapkan hasil yang sama diperoleh dari kegiatan pelatihan Ms. Word di SDN 173529 Tampahan. Tujuannya adalah supaya guru-guru paham dalam mengoperasikan Ms. Word. Jika guru sudah mampu mengoperasikan Ms. Word, maka guru akan mampu mengelola Dapodik secara mandiri, menyusun karya ilmiah sendiri dan membuat Rencana Pelaksanaan Pembelajaran (RPP) sendiri.

\section{Pendampingan Peningkatan Kapasitas Skill Microsoft Word Guru}

Sesuai dengan metode kegiatan yang telah dipaparkan, proses kegiatan PKM dilakukan sesuai dengan metode tersebut. Langkah-langkah dari metode kegiatan tersebut adalah diskusi kelompok, musyawarah, pelatihan internal atau In-

\footnotetext{
${ }^{6}$ Muhammad Siam Priyono Nugroho et al., "Bantuan Komputer Dan Pelatihan Program Microsoft Word Bagi Guru Dan Murid Madrasah Ibtadiyah Muhammadyah Di Sukoharjo Dan Boyolali," Warta 13, no. 1 (2010): 20-28.

${ }^{7}$ I. Budiana, H.R., Sjafirah, N.A. dan Bakti, "Pemanfaatan Teknologi Informasi Dan Komunikasi Dalam Pembelajaran Bagi Para Guru SMPN 2 Kawali Desa Citeureup Kabupaten Ciamis,"

Dharmakarya: Jurnal Aplikasi Ipteks untuk Masyarakat 4, no. 1 (2015): 59-62.
} 
House Training, lokakarya atau workshop.

Diskusi kelompok dilakukan bersama-sama dengan tim PKM, mahasiswa, kelompok guru dan kepala sekolah. Hasil diskusi menghasilkan materi-materi apa yang akan dilatihkan adalah pengetahuan dasar dalam menyusun RPP dan bahan ajar. Metode pembelajaran yang dilaksana metode diskusi, tanya jawab, ceramah dan praktek.

Musyawarah juga dilakukan antara tim PKM, mahasiswa, kelompok guru dan kepala sekolah. Dari hasil musyawarah disepakati bahwa kegiatan dilakukan di sekolah tersebut. Ruangan yang digunakan adalah ruangan yang sudah dialiri listrik yaitu ruang kelas 3. Kegiatan juga dilakukan diluar jam sekolah yaitu mulai jam 12 sehingga tidak mengganggu proses pembelajaran.

Kegiatan pelatihan internal Ms. Word dimulai dengan pretest. Soal pretest berisi tentang materi tentang penggunaan Ms. Word. Soal pretest terdiri dari 20 soal. Melalui hasilpretestdiperoleh nilai rata-rata pengetahuan guru tentang Ms. Word senilai 30. Setelah kegiatan pelatihan selesai dilaksanakan, peserta kembali mengerjakan soal posttest dengan soal yang sama. Nilai rata-rata hasil posttest adalah 78,33. Dengan demikian jika ditinjau dari segi kemampuan atau kognisi, pelatihan Ms. Word menunjukkan adanya peningkatan pengetahuan pada guru-guru di SD Negeri 173529 Tampahan. Peningkatan tersebut dapat dilihat dari nilai ratarata pretest dan posttest. Pada nilai posttest senilai 78,33. Grafik dari peningkatan tersebut dapat dilihat pada grafik berikut. 


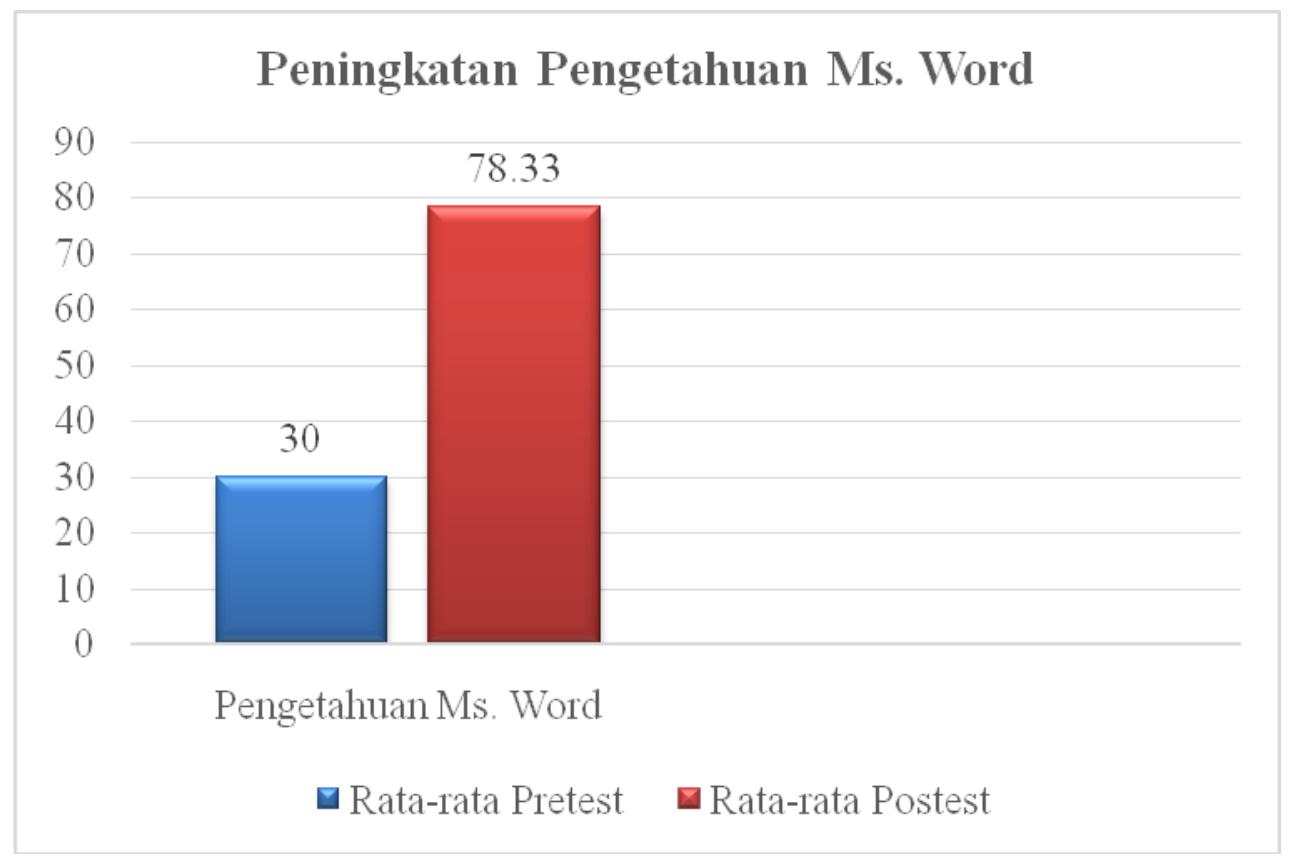

\section{Grafik 1.Grafik Peningkatan Pengetahuan Ms. Word}

Selain melakukan posttest, pada akhir kegiatan pelatihan juga diberikan angket kepada guru-guru. Hasil angket tentang pelatihan Ms. Word menunjukkan bahwa respon guru positif terhadap kegiatan pelatihan. Kesimpulan tersebut diambil dari 4 aspek yaitu aspek suka atau tidak suka, aspek baru atau tidak baru, aspek berminat atau tidak berminat dan aspek tertarik atau tidak tertarik. Untuk aspek suka atau tidak suka $100 \%$ guru menyukai materi pelatihan, $100 \%$ guru menyukai modul yang digunakan, $100 \%$ guru menyukai cara belajar pelatihan yang dilaksanakan dan $100 \%$ guru menyukai cara pemateri mengajar. Untuk aspek baru atau tidak baru $75 \%$ guru menyatakan bahwa materi pelatihan baru, $75 \%$ guru menyatakan bahwa modul yang digunakan baru, $75 \%$ guru menyatakan bahwa cara belajar baru dan $75 \%$ guru menyatakan bahwa cara pemateri mengajar baru. Untuk aspek berminat atau tidak berminat, $100 \%$ guru menyatakan berminat untuk melibatkan pembelajaran selanjutnya dengan materi pelatihan yang sudah dilaksanakan. Untuk aspek tertarik atau tidak tertarik, $100 \%$ guru menyatakan tertarik pada kegiatan pelatihan. Jika digambarkan dalam grafik, berikut adalah gambaran tentang respon guru pada setiap aspek. 


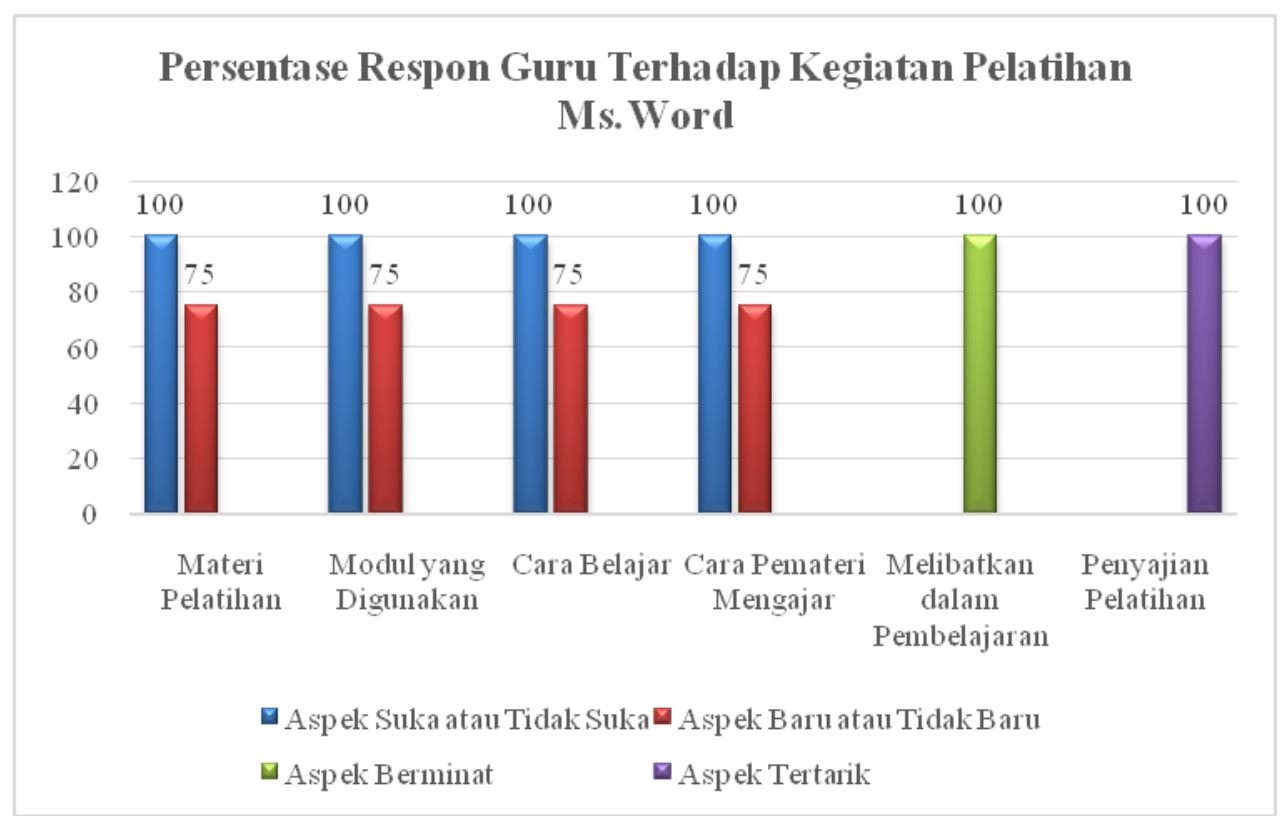

\section{Grafik 2. Persentase Respon Guru Terhadap Kegiatan Pelatihan Ms.Word}

Dalam implementasi workshop,tim pendampingmembagi guru menjadi dua kelompok yaitu kelompok guru kelas rendah dan kelompok guru kelas tinggi. Kegiatannya adalah membuat RPP dengan menggunakan Ms. Word. Hasil dari kegiatan tersebut adalah RPP dengan buatan guru sendiri. Berikut adalah dokumentasi kegiatan pelatihan Ms. Word.

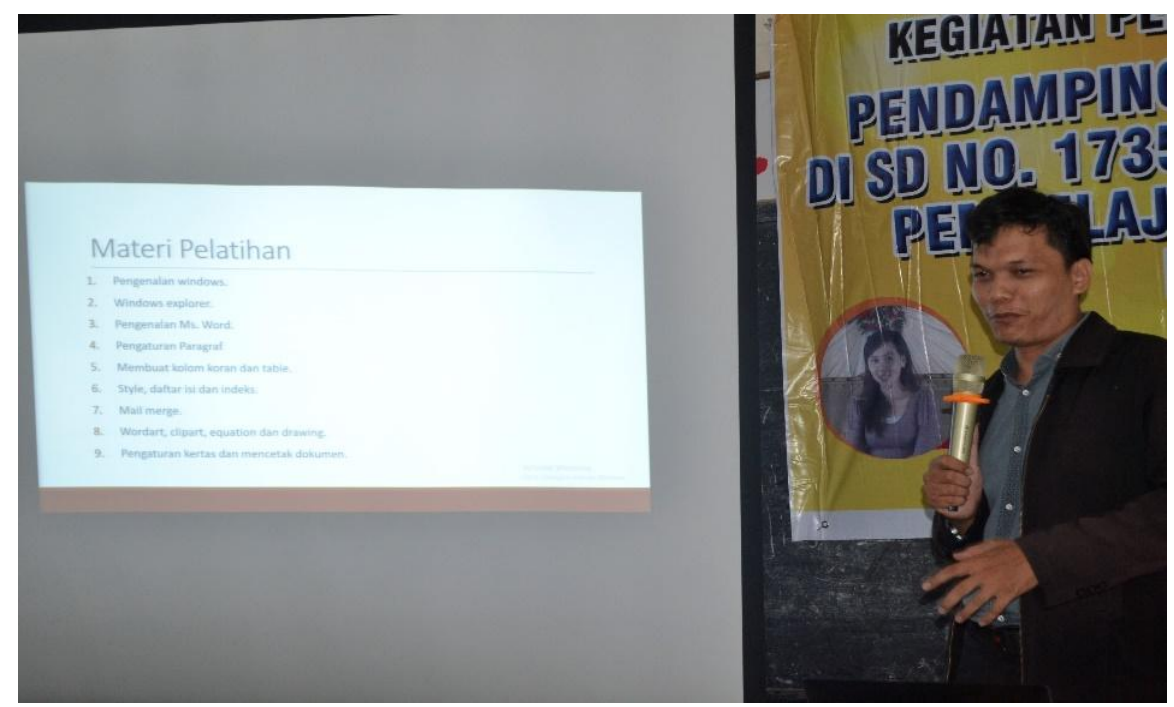

Gambar 1. Materi Pelatihan Ms. Word Oleh Ari Usman, ST., M. Kom 


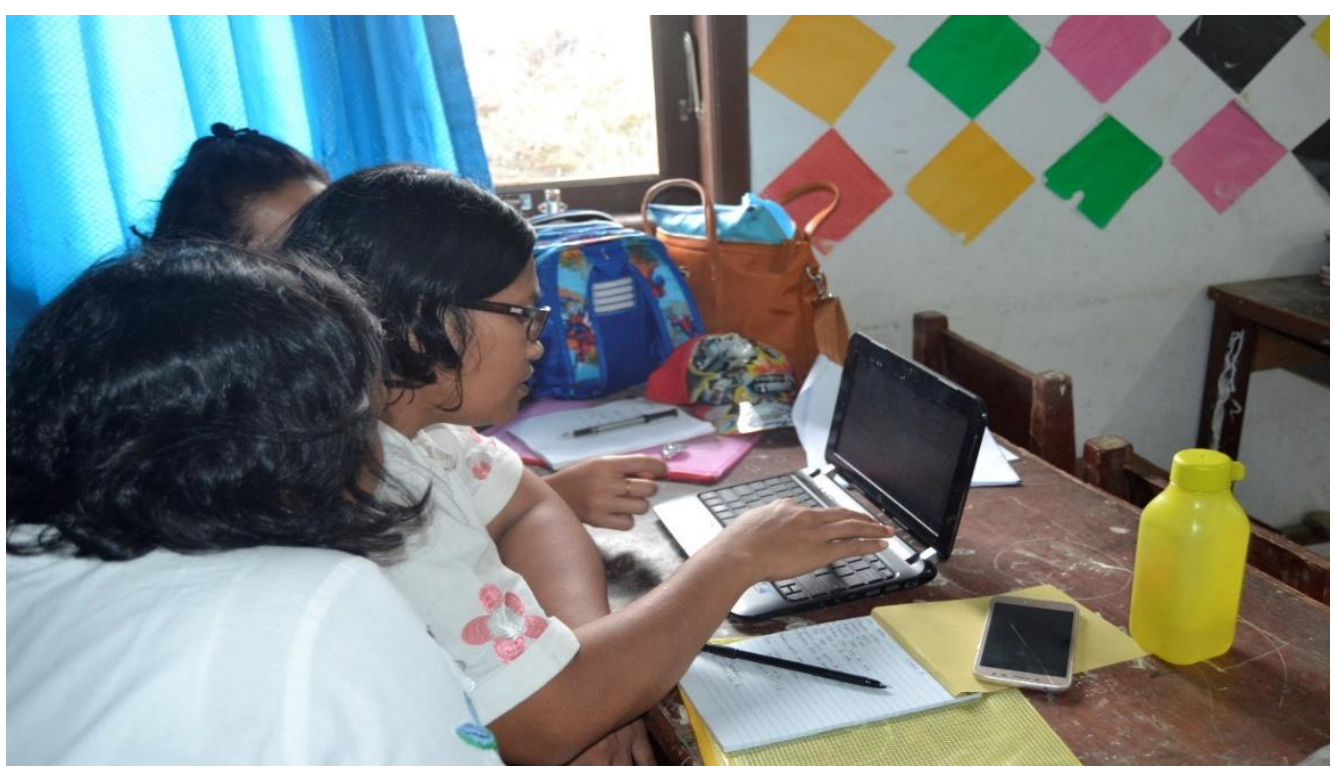

\section{Gambar 2. Praktek Ms. Word Oleh Guru-Guru}

Kondisi sekolah dengan gedung yang belum semua dialiri lisrtik sedikit banyak akan mempengaruhi kenyamanan guru dalam memanfaatkan teknologi seperti laptop dalam menunjang profesi guru. Namun, dengan pelatihan Ms. Word tersebut, guru akan lebih percaya diri dalam merancang RPP sendiri dan membuat karya ilmiah untuk kenaikan jabatan.

Dalam pelaksanaan kegiatan ini kesulitan yang dialami cukup tinggi. Guru sama sekali tidak paham membuka laptop dan membuka aplikasi yang diminta. Daya serap guru rendah dan lambat. Hasil kerja yang dikerjakan guru sering rusak dan hilang. Namun, seiring waktu dan latihan guru akan terbiasa menggunakan Ms. Word untuk mendukung profesionalitasnya sebagai guru.

Pada awal kegiatan guru mengaku membuat RPP hasil dari download dari internet dengan mengedit sebagian data. RPP tersebut kemudian diserahkan ke sekolah dan Dinas Pendidikan. Namun melalui pelatihan ini, guru-guru sudah mampu membuat RPP dengan menggunakan tabel dan membuat soal ujian menggunakan kolom. 


\section{Kesimpulan}

Simpulan yang diperoleh dari hasil kegiatan Pengabdian Kepada Masyarakat (PKM) setelah melalui pengolahan data dan analisis adalah terjadi peningkatan pengetahuan guru tentang Ms. Word dan guru memberikan respon yang positif terhadap kegiatan pelatihan Ms. Word yang dilaksanakan.

Metode pelatihan internal yang digunakan sudah cocok dengan kebutuhan guru. Melalui pelatihan internal, guru lebih fokus dan bebas untuk bertanya jika dibandingkan dengan kegiatan besar yang biasa dilaksanakan oleh pemerintah atau Dinas Pendidikan. Hal ini terlihat dari peningkatan kemampuan guru dalam mengoperasikan Ms Word tingkat dasar.

Dampak dari kegiatan adalah guru bersemangat untuk membuat RPP sendiri dan lebih percaya diri. Manfaat yang diperoleh oleh guru adalah guru mampu mengoperasikan Ms.Word dan menggunakannya untuk melengkapi administrasi sebagai guru seperti RPP dan karya ilmiah. Untuk kegiatan PKM selanjutnya sebaiknya adalah praktik dalam penyusunan bahan ajar sehingga dapat meningkatkan kemahiran dan penguasaan Ms. Word.

\section{Ucapan Terima Kasih}

Terima kasih kepada Kemenristekdikti yang sudah memberikan dana untuk kegiatan Pengabdian Kepada Masyarakat ini dengan nomor kontrak T/161/L1.3.1/PT.01.03/2019. Terima kasih juga kepada Dinas Pendidikan Kabupaten Toba Samosir, Kepala Sekolah dan guru-guru di SD Negeri 173529 yang sudah melakukan kerja sama yang baik demi lancarnya kegiatan Pengabdian Kepada Masyarakat ini. 
110 | Pendampingan Peningkatan Kapasitas Skill Microsoft Word ...

\section{Daftar Pustaka}

A Ilyas Ismail, M A. The True Da'wa: Menggagas Paradigma Baru Dakwah Era Milenial: Edisi Pertama. Prenada Media, 2018.

Budiana, H.R., Sjafirah, N.A. dan Bakti, I. "Pemanfaatan Teknologi Informasi Dan Komunikasi Dalam Pembelajaran Bagi Para Guru SMPN 2 Kawali Desa Citeureup Kabupaten Ciamis.” Dharmakarya: Jurnal Aplikasi Ipteks untuk Masyarakat 4, no. 1 (2015): 59-62.

Mudhofir, Ali. Pendidik Profesional: Konsep, Strategi, Dan Aplikasinya Dalam Peningkatan Mutu Pendidikan Di Indonesia. Jakarta: Raja Grafindo Persada, 2012.

Nugroho, Muhammad Siam Priyono, Suryaning Setyowati, Aliem Sudjatmiko, and dan Umi Fadlilah. "Bantuan Komputer Dan Pelatihan Program Microsoft Word Bagi Guru Dan Murid Madrasah Ibtadiyah Muhammadyah Di Sukoharjo Dan Boyolali." Warta 13, no. 1 (2010): 20-28.

Pianda, Didi. Kinerja Guru: Kompetensi Guru, Motivasi Kerja Dan Kepemimpinan Kepala Sekolah. CV Jejak (Jejak Publisher), 2018.

Sinaga, Bornok, and Manguji Nababan. Pengembangan Model Pembelajaran Matematika Berdasarkan Masalah Berbasis Budaya Batak (PBM-B3). Medan: FMIPA Unimed, 2008.

Sudijono, Anas. Pengantar Evaluasi Pendidikan. Jakarta: PT RajaGrafindo, 1998. 